\title{
Volumetric Determination of Columbium
}

\author{
By Howard B. Knowles and G. E. F. Lundell
}

\begin{abstract}
The quantitative determination of columbium based on reduction by amalgamated zinc and reoxidation with potassium permanganate has, in general, produced results that lack both accuracy and precision. A study of the various factors involved indicates that essential conditions require adequate duration of reduction in the presence of an excess of zinc and a proper concentration of both acid and columbium. A procedure is described whereby columbium, in a sulfuric acid solution, is quantitatively reduced by amalgamated zinc to the trivalent form and subsequently oxidized to the quinquevalent state.
\end{abstract}

\section{Introduction}

A method for the quantitative determination of columbium, depending on the reduction in acid solutions of quinquevalent columbium to the trivalent state by zinc, and subsequent titration with a standard solution of a suitable oxidant, has been the object of numerous investigations extending over a period of years. In brief, the procedures attempted have involved the treatment of a hydrochloric, a sulfuric, or a hydrofluoric acid solution of the columbium with zinc, usually amalgamated, and subsequent oxidation of the carefully protected solution directly, or indirectly through use of a ferric salt, with potassium permanganate. With but a single exception $[1]^{1}$ no reliable procedure based on the foregoing principle has been established that permits the use of stoichiometric values. A critical study of the procedures advocated by earlier investigators [2], in conjunction with the results obtained, is of little aid in indicating the underlying reason or cause for failure to obtain a quantitative reduction of this element. The use of material of unknown purity, imperfect procedures, doubtful conclusions, and other factors such as inadequate data, have all served separately or collectively to retard the solution of a rather difficult problem.

The present article concerns only the question of consistently obtaining complete and uniform

\footnotetext{
${ }_{1}$ Figures in brackets indicate the literature references at the end of this paper.
}

reduction of the columbium, such as would permit its use for quantitative determinations, and embodies results that have been obtained in an intermittent study of various related factors.

\section{Experimental Details}

\section{Amalgamation of Zinc}

A study of the reducing action of amalgamated zinc [3] indicates that for a number of elements it is requisite that the zinc be but lightly coated with mercury. Satisfactory amalgamation is accomplished as follows: Transfer 1,000 g of 20-mesh zinc metal (low in iron) to a stout, wide-mouthed glass bottle, add $500 \mathrm{ml}$ of a 2-percent aqueous solution of mercuric chloride, mix continuously for 45 to $60 \mathrm{sec}$, discard the solution, and wash five times with distilled water. Treat the washed amalgamated zinc with $500 \mathrm{ml}$ of warm, diluted sulfuric acid $(1+99)^{2}$, mix, discard the acid, and wash thoroughly with distilled water. The prepared amalgam is preferably preserved in water to which a few drops of hydrochloric acid have been added. The period of use of an amalgam thus prepared is limited. With continued use it eventually loses its efficiency and can no longer be used for this purpose.

\section{Sources of Columbium}

The two samples of columbium oxide used in the investigation were laboratory preparations. One was an oxide on which three different analysts

\footnotetext{
${ }^{2}$ Unless otherwise specified, concentrated reagents are meant.
} 
obtained 96.45, 96.53, and 96.42 percent of $\mathrm{Cb}_{2} \mathrm{O}_{5}$ by the tannin method [5]. A preferred average value of 96.43 percent for this sample would, for the purpose of reduction, be increased to an apparent 97.10 percent by the presence of 0.32 percent of $\mathrm{TiO}_{2}, 0.40$ percent of $\mathrm{Fe}_{2} \mathrm{O}_{3}$, and 0.08 percent of $\mathrm{Cr}_{2} \mathrm{O}_{3}$. A second sample of oxide was prepared from a specimen of columbium metal, spectroscopically free from titanium and tantalum. This specimen, however, contained traces of iron, copper, and tin, which were removed before preparation of the final $\mathrm{Cb}_{2} \mathrm{O}_{5}$. This sample was used on the basis of 100.00 -percent purity.

\section{Permissible Ācidity}

A study of the acid concentration necessary for the quantitative reduction of columbium indicates that the solution should contain preferably 20 percent by volume but never less than 15 percent by volume of sulfuric acid. With the latter concentration, there is a general tendency to slightly low but still satisfactory values. Under these conditions the reduced solution is clear and possesses an "amethyst-like" color. At lower concentrations of acid the reduced solution exhibits a dark (blackish) color and yields low values on titration.

The presence of small amounts of succinic acid, introduced as an aid to prevent hydrolysis, if not beneficial at least exerts no harmful influence.

\section{Concentration of Columbium Solution and Duration of Reduction}

Experiments indicate that essential factors for satisfactory reduction involve the time of contact of the solution with the amalgam, the amount of and concentration of the columbium to be reduced, and the amount of available zinc. The last, in turn, is a function of both the active area of the amalgam and the degree of amalgamation. In this study the time for the passage of all solutions through the reductor, unless otherwise noted, was not less than $25 \mathrm{~min}$. No study was made of the rate of reduction, a factor conditioned by other variables; but where only a few milligrams of columbium is involved, satisfactory reductions can undoubtedly be effected in less time. Two Jones' reductors of the conventional type containing columns of amalgamated zinc slightly less than 1 inch in diameter were used. One column was $18 \mathrm{in}$. in length and the other $33 \mathrm{in.}$
Definite limitations regarding the maximum concentrations for use with these or similar reductors are difficult to define because the solution, when introduced into the reductor, undergoes dilution and, due to nonuniform mixing, lacks homogeneity. Although concentrations of as high as $1.7 \mathrm{mg}$ of $\mathrm{Cb}_{2} \mathrm{O}_{5} / \mathrm{ml}$ have been reduced quantitatively at times with the long reductor, a study of all experiments indicates a concentration not greatly exceeding $1.0 \mathrm{mg} / \mathrm{ml}$ to be desirable. Similarly, the concentration for use with the short reductor should not exceed 0.7 to $0.8 \mathrm{mg} / \mathrm{ml}$.

\section{Temperature During Reduction}

Although heat is not essential to quantitative reduction [4], all reductions were conducted at a temperature of $65^{\circ} \pm 5^{\circ} \mathrm{C}$. This temperature facilitates the diffusion of zinc through the amalgam [3], and effects more vigorous action during passage of the solution through the reductor.

\section{Results}

The results of experiments obtained with two reductors under varying concentrations of acid and columbium are given in the following tables.

TABLE 1. Reductions effected in reductor with 33-in. column of zinc

\begin{tabular}{|c|c|c|c|}
\hline $\begin{array}{l}\text { Experiment } \\
\text { Number }\end{array}$ & $\begin{array}{l}\mathrm{Cb}_{2} \mathrm{O}_{5} \\
\text { taken }\end{array}$ & Error & Composition of $\mathrm{Cb}_{2} \mathrm{O}_{5}$ solution \\
\hline $\begin{array}{l}1 \\
2 \\
3 \\
4 \\
5 \\
6 \\
7 \\
8 \\
9 \\
10 \\
11 \\
12 \\
\end{array}$ & $\begin{array}{c}g \\
0.1048 \\
.1548 \\
.1993 \\
.2053 \\
.2503 \\
.2527 \\
.2535 \\
.3025 \\
.3418 \\
.3516 \\
.3513 \\
.3418\end{array}$ & $\begin{array}{c}g \\
+0.0005 \\
+.0005 \\
-.0003 \\
-.0001 \\
-.0002 \\
-.0016 \\
+.0004 \\
-.0002 \\
-.0004 \\
-.0038 \\
-.0017 \\
-.0127\end{array}$ & $\left\{\begin{array}{l}\text { 200-ml volume containing } 30 \mathrm{ml} \\
\text { of } \mathrm{H}_{2} \mathrm{SO}_{4}, 2 \mathrm{~g} \text { of succinic acid, } \\
\text { and } 1 \mathrm{ml} \text { of } \mathrm{H}_{2} \mathrm{O}_{2} \text { (30 percent). }\end{array}\right.$ \\
\hline $\begin{array}{l}13 \ldots \ldots \\
14 \\
15 \\
16 \ldots \ldots \\
17 \\
18 \\
19 \\
20 \\
21\end{array}$ & $\begin{array}{l}.0596 \\
.1017 \\
.1511 \\
.2062 \\
.2502 \\
.2535 \\
.3021 \\
.3405 \\
.3505\end{array}$ & $\begin{array}{l}+.0002 \\
+.0007 \\
+.0004 \\
+.0007 \\
+.0001 \\
+.0005 \\
+.0002 \\
+.0002 \\
-.0013\end{array}$ & $\left\{\begin{array}{l}200-\mathrm{ml} \text { volume containing } 40 \mathrm{ml} \\
\text { of } \mathrm{H}_{2} \mathrm{SO}_{4}, 2 \mathrm{~g} \text { of succinic acid, } \\
\text { and } 1 \mathrm{ml} \text { of } \mathrm{H}_{2} \mathrm{O}_{2}(30 \text { percent }) .\end{array}\right.$ \\
\hline $22 \ldots$ & $\begin{array}{l}.3512 \\
.3519\end{array}$ & $\begin{array}{l}-.0002 \\
-.0002\end{array}$ & $\left\{\begin{array}{l}300 \mathrm{ml} \text { volume containing } 60 \mathrm{ml} \\
\text { of } \mathrm{H}_{2} \mathrm{SO}_{4}, 3 \mathrm{~g} \text { of succinic acid, } \\
\text { and } 2 \mathrm{ml} \text { of } \mathrm{H}_{2} \mathrm{O}_{2} \text { (30 percent). }\end{array}\right.$ \\
\hline
\end{tabular}


TABLE 2. Reductions effected in reductor with 18-in. column of zinc

\begin{tabular}{|c|c|c|c|c|}
\hline $\begin{array}{c}\text { Experi- } \\
\text { ment } \\
\text { number }\end{array}$ & $\begin{array}{l}\mathrm{Cb}_{2} \mathrm{O}_{5} \\
\text { taken }\end{array}$ & Frror & $\begin{array}{l}\text { Composition of } \mathrm{Cb}_{2} \mathrm{O}_{5} \\
\text { solution }\end{array}$ & Remarks \\
\hline 1 & $\begin{array}{c}g \\
0.0502\end{array}$ & $\begin{array}{c}g \\
+0.0005\end{array}$ & \multirow{8}{*}{$\begin{array}{l}200-\mathrm{ml} \text { volume con- } \\
\text { taining } 30 \mathrm{ml} \text { of } \\
\mathrm{H}_{2} \mathrm{SO}_{4}, 2 \mathrm{~g} \text { of suc- } \\
\text { cinic acid, and } 1 \\
\text { ml } \mathrm{H}_{2} \mathrm{O}_{2} \text { (30 per- } \\
\text { cent) }\end{array}$} & \multirow{8}{*}{$\begin{array}{l}0.1020 \mathrm{~g} \text { of } \mathrm{TiO}_{2} \text { pres- } \\
\text { sent during reduc- } \\
\text { tion in experiment } \\
6 .\end{array}$} \\
\hline 2 & .0971 & -.0004 & & \\
\hline 3 & .0971 & -.0002 & & \\
\hline 4 & .0991 & -.0003 & & \\
\hline 5 & .1017 & +.0001 & & \\
\hline 6 & .1966 & -.0024 & & \\
\hline 7 & .1973 & -.0018 & & \\
\hline 8 & .1978 & -.0041 & & \\
\hline 9 & .0495 & .0000 & \multirow{13}{*}{$\begin{array}{l}200-\mathrm{ml} \text { volume con- } \\
\text { taining } 40 \mathrm{ml} \text { of } \\
\mathrm{H}_{2} \mathrm{SO}_{4}, 2 \mathrm{~g} \text { of suc- } \\
\text { cinic acid, and } 1 \\
\text { ml of } \mathrm{H}_{2} \mathrm{O}_{2}(30 \text { per- } \\
\text { cent) }\end{array}$} & \multirow{13}{*}{$\begin{array}{l}\text { Reduction effected } \\
\text { at } 25^{\circ} \mathrm{C} \text { in experi- } \\
\text { ment } 12 \text {. Freshly } \\
\text { amalgamated zine } \\
\text { used in experi- } \\
\text { ments } 20 \text { and } 21 .\end{array}$} \\
\hline 10 & .0971 & +.0006 & & \\
\hline 11 & .0971 & +.0005 & & \\
\hline 12 & .0973 & -.0006 & & \\
\hline 13 & .0976 & +.0004 & & \\
\hline 14 & .0979 & +.0006 & & \\
\hline 15 & .1005 & +.0005 & & \\
\hline 16 & .1005 & +.0003 & & \\
\hline 17 & .1006 & +.0005 & & \\
\hline 18 & .1030 & +.0005 & & \\
\hline 19 & .1519 & +.0004 & & \\
\hline 20 & .1958 & +.0006 & & \\
\hline 21 & .1959 & +.0004 & & \\
\hline $\begin{array}{l}22 \\
23 \\
24\end{array}$ & $\begin{array}{l}.0971 \\
.0981 \\
.0990\end{array}$ & $\begin{array}{l}-.0011 \\
-.0007 \\
-.0018\end{array}$ & $\left\{\begin{array}{l}200-\mathrm{ml} \text { volume con- } \\
\text { taining } 20 \mathrm{ml} \text { of } \\
\mathrm{H}_{2} \mathrm{SO}_{4}, 2 \mathrm{~g} \text { of suc- } \\
\text { cinic acid and } 1 \\
\mathrm{ml} \mathrm{H}_{2} \mathrm{O}_{2}(30 \text { per- } \\
\text { cent })\end{array}\right.$ & \multirow{8}{*}{$\begin{array}{l}\text { Duration of reduc- } \\
\text { tion } 12 \text { to } 15 \mathrm{~min} \text { in } \\
\text { experiments } 25 \text { to } \\
28 \text {,inclusive. } 0.1509 \\
\mathrm{~g}, 0.1006 \mathrm{~g} \text { and } \\
0.1660 \mathrm{~g} \text { of } \mathrm{TiO}_{2} \\
\text { present during re- } \\
\text { duction in experi- } \\
\text { ments } 25,26 \text {, and } \\
27 \text {, respectively. }\end{array}$} \\
\hline 25 & .0978 & -.0005 & \multirow{6}{*}{$\begin{array}{l}100-\mathrm{ml} \text { volume con- } \\
\text { taining } 20 \mathrm{ml} \text { of } \\
\mathrm{H}_{2} \mathrm{SO}_{4}, 1 \mathrm{~g} \text { of suc- } \\
\text { cinic acid and } 1 \mathrm{ml} \\
\mathrm{H}_{2} \mathrm{O}_{2}(30 \text { percent). }\end{array}$} & \\
\hline 26 & .0982 & -.0006 & & \\
\hline 27 & .1032 & -.0006 & & \\
\hline 28 & .1032 & -.0012 & & \\
\hline 29 & .1046 & -.0001 & & \\
\hline 30 & .1947 & -.0018 & & \\
\hline 31 & .1942 & +.0004 & $\begin{array}{l}300 \text {-ml volume con- } \\
\text { taining } 60 \mathrm{ml} \text { of } \\
\mathrm{H}_{2} \mathrm{SO}_{4}, 3 \mathrm{~g} \text { of suc- } \\
\text { cinic acid, and } 2 \\
\text { ml } \mathrm{H}_{2} \mathrm{O}_{2}(30 \text { per- } \\
\text { cent }) \text {. }\end{array}$ & \\
\hline
\end{tabular}

\section{Discussion}

A study of the results recorded in tables 1 and 2 indicates that solutions containing 20 percent of sulfuric acid by volume tend to yield slightly positive values, whereas those containing 15 percent are somewhat low. No study of this variation was undertaken, but in a few experiments the presence of traces of hydrogen sulfide was indicated, notably in solutions of higher acid concentration, by a slight discoloration of moistened lead-acetate paper on contact with the gases evolved. A similar case has been noted during the reduction of chromium solutions [6].

The presence of added titanium dioxide, as recommended by some investigators [1, 7] as an aid in securing uniform and complete reduction, does not appear to be a requisite. Experiments 6, 25,26 , and 27 of table 2 yielded slightly low results in the presence of this constituent but gave, on repetition in the absence of titania, equally unsatisfactory values, thus indicating other factors as a source of error.

A reconciliation of the differences between experiments 6,7 , and 8 with 20 and 21 of table 2 and experiments 11 and 21 with 9 and 20 of table 1 is difficult because of the factors involved. The low and unsatisfactory values obtained in these experiments are believed to be largely due to the amount and concentration of columbium that each reductor is capable of handling, although other factors, such as a lower concentration of acid and the age of the reductors, may have exerted contributory effects. A repetition of the experiments yielding low results, in a somewhat larger volume of solution, gave satisfactory results as is shown by experiment 31 of table 2 and experiments 22 and 23 of table 1. A study of the results indicates that for a satisfactory reduction it is necessary to maintain the proper relationship between both the concentration and amount of columbium to be reduced and the size of the reductor that is to be used.

Experiments 6, 10, and 12 of table 1 indicate progressively the failure of an amalgam that had proved satisfactory in a series of 11 prior determinations involving a total of $2.66 \mathrm{~g}$ of $\mathrm{Cb}_{2} \mathrm{O}_{5}$. The smaller reductor, used in the experiments recorded in table 2, gave no indication of exhaustion at the conclusion of a series of 14 determinations involving $1.46 \mathrm{~g}$ of oxide.

With the reductors employed in the present investigation, desirable limits appear to be 300 $\mathrm{mg}$ of $\mathrm{Cb}_{2} \mathrm{O}_{5}$ contained in a volume of $200 \mathrm{ml}$ for the 33 -in. reductor and $175 \mathrm{mg}$ in a similar volume for a reductor with an 18 -in. column. The above quantities may be materially increased if larger volumes of the $\mathrm{Cb}_{2} \mathrm{O}_{5}$ solution to be reduced, at the appropriate acid concentration, are employed.

Solutions containing as impurities elements that are reduced to metal by zinc should not be introduced into the reductor, since their presence tends to result in an unnecessarily violent evolution of hydrogen. 


\section{Recommended Procedure}

The following procedure describes conditions suitable for solutions that may contain as much as $300 \mathrm{mg}$ of $\mathrm{Cb}_{2} \mathrm{O}_{5}$ and requires the use of a reductor having a long column of amalgamated zinc. With solutions containing not more than $175 \mathrm{mg}$ of the oxide, satisfactory reductions can be effected in a shorter reductor, such as one with an 18-in. column.

Fuse a dry weighed sample of not more than $300 \mathrm{mg}$ of the oxide in a $25-\mathrm{ml}$ covered silica (or equivalent) crucible with 3 to $5 \mathrm{~g}$ of potassium pyrosulfate. Cool, transfer the covered crucible with contents to a covered $250-\mathrm{ml}$ beaker, add $20 \mathrm{ml}$ of sulfuric acid, and heat moderately to dissolve the melt. Cool, add 1 to $2 \mathrm{ml}$ of hydrogen peroxide $(30 \%)$, cautiously dilute with $100 \mathrm{ml}$ of water, and rinse and remove the crucible and cover. Cool, add $20 \mathrm{ml}$ of sulfuric acid, dilute to $200 \mathrm{ml}$ with water, add $2 \mathrm{~g}$ of succinic acid, and heat moderately, while stirring, until the succinic acid dissolves.

Reduce the columbium in a reductor having a 33-in. column in the following manner: First clean and preheat the reductor by pouring through it hot diluted sulfuric acid $(1+19)$ and then hot water $\left(90^{\circ} \mathrm{C}\right)$. Discard the washings. Place a three-fold excess of ferric iron in the receiver and attach to the reductor. Pour into the reductor $100 \mathrm{ml}$ of sulfuric acid $(1+4)$ heated to $65^{\circ} \pm 5^{\circ} \mathrm{C}$. With the aid of suction draw the foregoing solution, the solution of the columbium, $150 \mathrm{ml}$ of sulfuric

${ }^{3}$ During reduction, particularly during passage of the columbium solution' the reductor alternately fills and empties due to formation of gas. This condition, although resulting in a nonuniform rate of passage of the solution, is normal and should not be disturbed. With volumes of columbium solution exceeding $200 \mathrm{ml}$, the time of reduction is materially increased. acid $(1+4)$ containing 1 percent of succinic acid, each at $65^{\circ} \pm 5^{\circ} \mathrm{C}$, and 200 to $250 \mathrm{ml}$ of cold water slowly through the reductor without interruption at such a rate (unchanged) that the total time for the passage of all solutions is not less than $25 \mathrm{~min}^{3}$ Cool the solution of reduced columbium by immersion of the receiver in ice water during the operation. Remove the receiver from the reductor, rinse and drain the outlet tube in the customary manner. Add $10 \mathrm{ml}$ of phosphoric acid $(85 \%)$ and titrate with a $0.1-N$ solution of potassium permanganate $\left(0.0066455 \mathrm{~g}\right.$ of $\mathrm{Cb}_{2} \mathrm{O}_{5} /$ $\mathrm{ml}$ ) [8], using orthophenanthroline as an indicator. Correct the titration by deducting the amount of potassium permanganate consumed by a blank determination, involving all reagents, obtained under identical conditions. To insure absence of oxidizable impurities each of the acid-wash solutions is permanently tinted, while hot, by the addition of a few drops of a solution of potassium permanganate.

\section{References}

[1] T. R. Cunningham, Ind. Eng. Chem., Anal. Ed. 10, 233 (1938).

[2] W. R. Schoeller and E. F. Waterhouse, Analyst, 49, 215 (1924).

[3] H. W. Stone and D. N. Hume, Ind. Eng. Chem., Anal. Ed. 11, 598 (1939); H. A. Liebhafsky, J. Am. Chem. Soc. 59, 452 (1937).

[4] G. E. F. Lundell and H. B. Knowles, Ind. Eng. Chem. 16, 823 (1924).

[5] W. R. Schoeller, Analyst 57, 750 (1932).

[6] J. R. Branham, J. Research NBS 21, 45 (1938) RP1112.

[7] W. D. Treadwell, Helv. Chim. Acta 5, 806 (1922).

[8] R. M. Fowler and H. A. Bright, J. Research NBS 15, 493 (1935) RP843.

Washington, December 13, 1948. 